ЭФФЕКТИВНОСТЬ

ИНТЕНСИФИКАЦИИ МОЛОЧНОГО

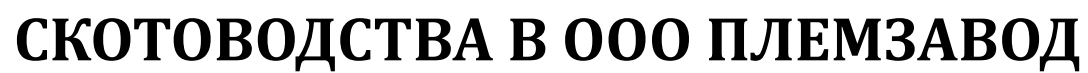
«КРАСНЫЙ МАЯК» ЯРОСЛАВСКОЙ ОБЛАСТИ

\section{Р.В. Тамарова}

д.С-Х.Н., профессор, профессор кафедры зоотехнии ФГБОУ ВО Ярославская ГСХА, г. Ярославль

В Ярославской области с 2005 года активно реализуется государственная программа развития АПК, особенно в животноводстве, составляющем основную отрасль сельскохозяйственного производства.

Интенсификация молочного скотоводства началась ещё в начале 90-х годов XX века, но особенно усилилась с переходом к рыночной экономике, вступлением России в ВТО и Таможенный союз [1]. Коренным образом изменилась и система племенной работы с молочными стадами - от чистопородного разведения ярославского скота, бывшего в области единственной породой, перешли к межпородному скрещиванию с использованием лучшего мирового генофонда [2], а с 2006 года стали закупать чистопородный импортный скот, преимущественно голштинской породы, самой обильномолочной из всех мировых пород $[3,4]$.

С 2005 по 2017 год в Ярославской области построено и модернизировано 33 крупных молочных комплекса на 23 тысячи скотомест и планируется построить ещё 9 комплексов с беспривязным содержанием коров $(34,5 \%)$ и высокопроизводительными доильными установками. Маточное поголовье этих комплексов формируется, в основном, за счёт импортного скота, ввиду недостаточности собственного воспроизводства.

По данным Департамента АПК и потребительского рынка Ярославской области, за 10 лет закуплено 23269 голов племенного молодняка, в том числе голштинской породы - 52,7\%, чёрно-пёстрой голштинизированной - 17,4\%, ярославской - 22,6\%, симментальской $-4,3 \%$, айрширской - 2,3\%, джерсейской - 0,8\%.

Планируется ещё закупка нетелей 7-месячной стельности, так как заполнено лишь 76,6\% скотомест [5].

Одним из хозяйств, радикально преобразовавшим систему ведения молочного скотоводства, является ООО «Красный Маяк» Ростовского муниципального района. С 2004 года здесь стали вести скрещивание коров с голштинскими быками. Хозяйство было товарным, с относительно невысокой продуктивностью стада коров ярославской породы (несколько выше 4 тыс. кг молока в среднем на 1 фуражную корову в год). С повышением годовых удоев до уровня более 6 тысяч кг молока ООО «Красный Маяк» получило статус племрепродуктора по ярославской породе. За два года (2014-2015 гг.) 
был построен комплекс на 2000 скотомест с механизацией трудоёмких процессов, доильной площадкой «Карусель» и другим оборудованием. Для комплектования маточного стада было закуплено и поставлено на комплекс 1173 голштинских нетели из Нидерландов, а затем ещё 370 нетелей из Восточной Германии. С 2018 года это хозяйство стало племзаводом по голштинской породе.

В тематике НИР научной школы по направлению 36.02 .07 - разведение, селекция и генетика сельскохозяйственных животных одна из задач исследование эффективности разведения импортного скота селекции разных стран в наших условиях, изучение проблем акклиматизации, адаптации, хозяйственно-полезных качеств животных, в итоге - разработка научно обоснованной системы производственного использования таких животных, с минимизацией рисков и экономических потерь.

Цель данных исследований - изучить в динамике эффективность интенсификации молочного скотоводства в указанном хозяйстве, проанализировать в комплексе производственные показатели с учётом всех аспектов и проблем.

Задачи исследований:

- дать сравнительную оценку результатов межпородного скрещивания животных ярославской и голштинской пород;

- оценить молочную продуктивность коров стада разных генетических групп;
- провести анализ продолжительности хозяйственного использования импортного скота и причины выбраковки животных;

- оценить состояние воспроизводства стада, рост и развитие ремонтных тёлок;

- проследить рост валового надоя молока и его товарности;

- проанализировать экономические показатели.

Информационной базой являлись данные бонитировок животных стада за 2011-2018 годы, проведённых ОАО «Ярославское» по племенной работе, годовые отчёты хозяйства о производственно-экономической деятельности.

Методы исследований - общезоотехнические, а именно: метод сплошного обследования всего поголовья, сравнительный анализ показателей в динамике по годам за период 7 лет.

\section{Результаты исследований}

За точку отсчёта при анализе показателей нами взят 2011 год, когда хозяйство получило статус племрепродуктора по ярославской породе. Следует отметить, что улучшение стада методом межпородного скрещивания началось с 2004 года, и наилучшие результаты получены в 2015 году, когда голштино-ярославские помеси составляли 73\% от общего поголовья коров, а их средний удой за стандартную лактацию был 8181 кг молока, или +1894 кг $(30,1 \%)$ к ярославским

Таблица 1 - Результаты скрещивания ярославских коров с голштинскими быками (по данным бонитировок)

\begin{tabular}{|c|c|c|c|c|c|c|}
\hline \multirow{2}{*}{ Показатель } & \multicolumn{3}{|c|}{ Год } & \multirow{2}{*}{$\begin{array}{c}2015 \text { г. } \\
\text { к } 2011 \text { г., \% }\end{array}$} & \multirow{2}{*}{$\begin{array}{c}2018 \text { г. } \\
\text { к } 2015 \text { г., \% }\end{array}$} & \multirow{2}{*}{$\begin{array}{c}2018 \text { г. } \\
\text { к } 2011 \text { г., \% }\end{array}$} \\
\hline & 2011 & 2015 & 2018 & & & \\
\hline $\begin{array}{l}\text { Количество помесного скота, } \\
\text { гол. }\end{array}$ & 414 & 679 & 616 & 164,0 & 90,7 & 148,8 \\
\hline в т.ч. коров, гол. & 178 & 244 & 286 & 137,1 & 117,2 & 160,7 \\
\hline к общему поголовью, \% & 40,2 & 73,0 & 86,4 & 32,8 п.п. & 13,4 п.п. & 46,2 п.п. \\
\hline Средний удой помесей, кг & 6133 & 8181 & 9577 & 133,4 & 117,1 & 156,2 \\
\hline МДЖ, \% & 4,07 & 4,21 & 3,98 & 0,14 п.п. & -0,23 п.п. & -0,09 п.п. \\
\hline МДБ, \% & 3,33 & 3,35 & 3,20 & 0,02 п.п. & -0,15 п.п. & -0,13 п.п. \\
\hline Молочный жир, кг & 249,6 & 344,4 & 381,1 & 138,0 & 110,7 & 152,7 \\
\hline Молочный белок, кг & 204,2 & 274,0 & 306,4 & 134,2 & 111,8 & 150,0 \\
\hline MЖ+MБ, кг & 453,8 & 618,4 & 687,5 & 136,3 & 111,2 & 151,5 \\
\hline Средняя живая масса, кг & 515 & 551 & 539 & 107,0 & 97,8 & 104,7 \\
\hline $\begin{array}{l}\text { Количество ярославских } \\
\text { чистопородных сверстниц, гол. }\end{array}$ & 265 & 73 & 37 & 27,5 & 50,7 & 14,0 \\
\hline К общему поголовью, \% & 59,8 & 27,0 & 13,6 & $-32,8$ п.п. & -13,4 п.п. & -46,2 п.п. \\
\hline
\end{tabular}


чистопородным сверстницам (табл. 1). Более детально эффект интенсификации можно проследить по данным таблиц 1-6.

К 2011 году поголовье помесных коров составляло $40,2 \%$ от общего стада, а продуктивность их - 6133 кг молока жирностью 4,07\%, белка - 3,33\%.

Суммарный выход молочного жира и белка составил 453,8 кг. Ярославских чистопородных сверстниц помеси превышали по удою на 286 кг, или на 4,9\%, а по содержанию жира и белка уступали им на 0,03\%.

К 2018 году превышение по удою составило 3444 кг, или 56,2\%, молочного жира и белка на $51,5 \%$ больше, при некотором снижении абсолютных показателей жира и белка в молоке - на 0,09-0,13\%. По живой массе помеси на 24 кг, или на $4,7 \%$, превосходили ярославских сверстниц.

С разведением импортного чистопородного голштинского скота поголовье помесных и особенно ярославских чистопородных коров стало уменьшаться, а общие показатели поголовья и продуктивности стада - возрастать (табл. 2).
В 2018 году поголовье коров увеличилось до 2150 голов (в 3,7 раза к 2011 году), удои возросли с 6225 до 10457 кг, или на 68\%. МДЖ и МДБ снизились на 0,09 и 0,11\% соответственно, однако выход за лактацию молочного жира и белка возрос на 291 кг, или на 63,4\%.

Средняя живая масса коров увеличилась на 26 кг, или 5\%. Число коров с удоем более 6000 кг за лактацию возросло на 1997 голов, или в 13,7 раза.

Увеличилась и продуктивность первотёлок: их удои возросли с 5943 кг до 9420 кг, или на 58,5\%. При снижении содержания жира и белка в молоке на 0,15-0,13\% выход молочного жира и белка за лактацию увеличился на 51,8\% (+228,8 кг). Средняя живая масса коров увеличилась на 37 кг, или 7,4\%.

Валовый надой молока увеличился в 6,5 раза - с 36583 до 236048 ц. Товарность молока почти сохранилась на прежнем уровне - рост на 2,5\% (до 96,5\%), и она достаточно высокая (только $3,5 \%$ получаемого молока остаётся в хозяйстве на выпойку телятам).

Продолжение таблицы 1

\begin{tabular}{|c|c|c|c|c|c|c|}
\hline \multirow{2}{*}{ Показатель } & \multicolumn{3}{|c|}{ Год } & \multirow{2}{*}{$\begin{array}{c}2015 \text { г. } \\
\text { к } 2011 \text { г., \% }\end{array}$} & \multirow{2}{*}{$\begin{array}{c}2018 \text { г. } \\
\text { к } 2015 \text { г., \% }\end{array}$} & \multirow{2}{*}{$\begin{array}{c}2018 \text { г. } \\
\text { к } 2011 \text { г., \% }\end{array}$} \\
\hline & 2011 & 2015 & 2018 & & & \\
\hline $\begin{array}{l}\text { Средний удой ярославских } \\
\text { чистопородных сверстниц, } \\
\text { кг }\end{array}$ & 5847 & 6287 & 6042 & 107,5 & 96,1 & 103,3 \\
\hline Помеси \pm к сверстницам, \% & 4,9 & 30,1 & 58,5 & 25,2 п.п. & 28,4 п.п. & 53,6 п.п. \\
\hline $\begin{array}{l}\text { МДЖ ярославских чистопо- } \\
\text { родных сверстниц, \% }\end{array}$ & 4,13 & 4,30 & 4,32 & 0,17 п.п. & 0,02 п.п. & 0,19 п.п. \\
\hline Помеси \pm к сверстницам, \% & $-0,06$ & $-0,09$ & $-0,02$ & -0,03 п.п. & 0,07 п.п. . & 0,04 п.п. . \\
\hline $\begin{array}{l}\text { МДБ ярославских чистопо- } \\
\text { родных сверстниц, \% }\end{array}$ & 3,39 & 3,42 & 3,43 & 0,03 п.п. & 0,01 п.п. & 0,04 п.п. \\
\hline Помеси \pm к сверстницам, \% & $-0,06$ & $-0,07$ & $-0,01$ & -0,01 п.п. & 0,06 п.п. & 0,05 п.п. \\
\hline $\begin{array}{l}\text { МЖ ярославских чистопо- } \\
\text { родных сверстниц, кг }\end{array}$ & 241,5 & 270,3 & 261,0 & 111,9 & 96,6 & 108,1 \\
\hline Помеси \pm к сверстницам, \% & 3,3 & 27,3 & 46,0 & 24,0 п.п. & 18,7 п.п. & 42,7 п.п. \\
\hline $\begin{array}{l}\text { МБ ярославских чистопо- } \\
\text { родных сверстниц, кг }\end{array}$ & 198,2 & 215,0 & 207,2 & 108,5 & 96,4 & 104,5 \\
\hline Помеси \pm к сверстницам, \% & 3,0 & 27,4 & 32,3 & 24,4 п.п. & 4,9 п.п. & 29,3 п.п. \\
\hline $\begin{array}{l}\text { МЖ+МБ ярославских чисто- } \\
\text { породных сверстниц, кг }\end{array}$ & 439,7 & 485,3 & 468,2 & 110,4 & 96,5 & 106,5 \\
\hline $\begin{array}{l}\text { Помеси } \pm \text { к сверстницам, } \\
\text { кг/\% }\end{array}$ & 3,2 & 27,4 & 31,8 & 24,2 п.п. & 4,4 п.п. & 28,6 \\
\hline $\begin{array}{l}\text { Средняя живая масса } \\
\text { ярославских чистопород- } \\
\text { ных сверстниц, кг }\end{array}$ & 503 & 550 & 547 & 109,3 & 99,5 & 108,7 \\
\hline
\end{tabular}


Таблица 2 - Молочная продуктивность коров стада ООО «Красный Маяк» в динамике по периодам

\begin{tabular}{|c|c|c|c|c|c|c|}
\hline \multirow{2}{*}{ Показатель } & \multicolumn{3}{|c|}{ Год } & \multirow{2}{*}{$\begin{array}{c}2015 \text { г. } \\
\text { к } 2011 \text { г., \% }\end{array}$} & \multirow{2}{*}{$\begin{array}{c}2018 \text { г. } \\
\text { к } 2015 \text { г., \% }\end{array}$} & \multirow{2}{*}{$\begin{array}{c}2018 \text { г. } \\
\text { к } 2011 \text { г., \% }\end{array}$} \\
\hline & 2011 & 2015 & 2018 & & & \\
\hline Поголовье коров, гол. & 585 & 690 & 2150 & 117,9 & в 3,1 раза & в 3,7 раза \\
\hline Средний удой за 305 дней, кг & 6225 & 8749 & 10457 & 140,5 & 119,5 & 168,0 \\
\hline Мдж, \% & 4,06 & 4,22 & 3,97 & 0,16 п.п. & -0,25 п.п. & -0,09 п.п. \\
\hline МДБ, \% & 3,31 & 3,36 & 3,20 & 0,05 п.п. & -0,16 п.п. & -0,11 п.п. \\
\hline Молочный жир, кг & 252,7 & 369,2 & 415,1 & 146,1 & 112,4 & 164,3 \\
\hline Молочный белок, кг & 206,0 & 294,0 & 334,6 & 142,7 & 113,8 & 162,4 \\
\hline МЖ+МБ, кг & 458,7 & 663,2 & 749,7 & 144,6 & 113,0 & 163,4 \\
\hline Средняя живая масса, кг & 519 & 550 & 545 & 106,0 & 99,1 & 105,0 \\
\hline $\begin{array}{l}\text { Количество коров с удоем > } \\
6000 \text { кг, гол. }\end{array}$ & 157 & 536 & 2150 & в 3,4 раза & в 4,0 раза & в 13,7 раза \\
\hline $\begin{array}{l}\text { в том числе первотёлок: } \\
\text { - средний удой за } 305 \text { дней, кг }\end{array}$ & 5943 & 8252 & 9420 & 138,9 & 114,2 & 158,5 \\
\hline - МДЖ, \% & 4,02 & 4,21 & 3,87 & 0,19 п.п. & -0,34 п.п. & -0,15 п.п. \\
\hline - МДБ, \% & 3,32 & 3,36 & 3,19 & 0,04 п.п. & $-0,17$ & -0,13 п.п. \\
\hline - молочный жир, кг & 238,9 & 347,4 & 364,5 & 145,4 & 104,9 & 152,6 \\
\hline - молочный белок, кг & 197,3 & 277,2 & 300,5 & 140,5 & 108,4 & 152,3 \\
\hline - МЖ + МБ, кг & 436,2 & 629,6 & 662,0 & 144,3 & 105,1 & 151,8 \\
\hline - средняя живая масса, кг & 498 & 538 & 535 & 108,0 & 99,4 & 107,4 \\
\hline Валовый надой, ц & 36583 & 48193 & 236048 & 131,7 & в 4,9 раза & в 6,5 раза \\
\hline Товарность молока, \% & 94,0 & 96,1 & 96,5 & 2,1 п.п. & 0,4 п.п. & 2,5 п.п. \\
\hline Средний возраст стада, отёлов & 2,4 & 2,3 & 2,1 & 95,8 & 91,3 & 87,5 \\
\hline
\end{tabular}

Незначительно уменьшился средний возраст стада в отёлах (на 0,3), то есть стадо очень молодое. Средний возраст выбытия коров (продолжительность использования) сократился с 3 до 2,3 отёлов $(-0,7)$, на $6,3 \%$ увеличилось выбытие коров.

Ремонт стада (ввод нетелей) составил $34 \%$, а выбраковка первотёлок - 28,6\%, что естественно для такого большого поголовья. В целом по стаду выбраковка коров увеличилась на 9,9\%.

Основные причины выбраковки коров - гинекология и яловость - 20,2\% (было 40,5\%), болезни конечностей - 18,8\% (было 23-33\%), болезни вымени (увеличились с 10,5 до 15,2\%), возросло также число травм и несчастных случаев - с 4,2 до 16,7\%, а выбраковка из-за низкой продуктивности, наоборот, снизилась с 7 до 0,8\% (табл. 3).

Повысилась скороспелость тёлок: средний возраст первого отёла уменьшился на 112 дней, или 86,5\%. Живая масса тёлок при этом стала крупнее на 7,9\%. Продажа племмолодняка увеличилась в 7,7 раза (с 10 до 77 голов, в том числе быков 11 голов), что выгодно экономически (табл. 4).
Как видно из таблицы 5, улучшилось состояние воспроизводства стада: выход телят увеличился с 75 до 83\%. Быками-улучшателями осеменили $74,4 \%$ маточного поголовья. Сервис-период сократился на 27 дней, то есть повысилась оплодотворяемость коров, что уменьшает потери молока от яловости.

Из таблицы 6 видно, что в 6,5 раза возросли показатели валового надоя и производства молока в сутки, в 2,2 раза увеличилась прибыль от реализации молока к общей выручке (в процентах), повысилась конверсия корма (сократились затраты кормов на 1 кг молока), увеличилась рентабельность производства молока. Общая прибыль от отрасли животноводства в 2018 году составила $74,9 \%$ от общей выручки, или 678,9 млн руб., в том числе от реализации молока - свыше $94 \%$. Выручка от реализации всей сельскохозяйственной продукции - 905,3 млн руб.

Система кормления коров - американская, с преобладанием концкормов (до 50\%) и силоса, небольшим удельным весом объёмистых грубых кормов. Кукурузного силоса заготавливают 14360 
Таблица 3 - Выбраковка коров и её причины, ремонт стада

\begin{tabular}{|c|c|c|c|c|c|c|}
\hline \multirow{2}{*}{ Показатель } & \multicolumn{3}{|c|}{ Год } & \multirow{2}{*}{$\begin{array}{c}2015 \text { г. } \\
\text { к } 2011 \text { г., } \pm\end{array}$} & \multirow{2}{*}{$\begin{array}{c}2018 \text { г. } \\
\text { к } 2015 \text { г., } \pm\end{array}$} & \multirow{2}{*}{$\begin{array}{c}2018 \text { г. } \\
\text { К } 2011 \text { г., } \pm\end{array}$} \\
\hline & 2011 & 2015 & 2018 & & & \\
\hline Выбыло коров, гол. & 173 & 179 & 659 & +6 & +480 & +486 \\
\hline Выбыло коров, \% & 24,4 & 25,9 & 30,7 & $+1,5$ & $+4,8$ & $+6,3$ \\
\hline $\begin{array}{l}\text { Средний возраст выбытия, } \\
\text { отёлы }\end{array}$ & 3,0 & 3,5 & 2,3 & $+0,5$ & $-1,2$ & $-0,7$ \\
\hline $\begin{array}{l}\text { Причины выбраковки, \%: } \\
\text { - гинекология, яловость }\end{array}$ & 40,5 & 19,5 & 20,2 & $-21,0$ & $+0,7$ & $-20,3$ \\
\hline - болезни ног & 23,1 & 33,5 & 18,8 & $+10,4$ & $-14,7$ & $-4,3$ \\
\hline - болезни вымени & 10,5 & 14,5 & 15,2 & $+4,0$ & $+0,7$ & $+4,7$ \\
\hline - низкая продуктивность & 7,0 & 0,6 & 0,8 & $-6,4$ & $+0,2$ & $-6,2$ \\
\hline - травмы, несчастные случаи & 4,2 & 6,7 & 16,7 & $+2,5$ & $+10,0$ & $+12,5$ \\
\hline $\begin{array}{l}\text { Растелилось нетелей: } \\
\text { - гол. }\end{array}$ & 214 & 199 & 678 & -15 & +479 & +464 \\
\hline$-\%$ & 42,0 & 33,0 & 34,0 & $-9,0$ & $+1,0$ & $-8,0$ \\
\hline $\begin{array}{l}\text { Выбраковано: } \\
\text { - гол. }\end{array}$ & 40 & 30 & 194 & -10 & +164 & +154 \\
\hline$-\%$ & 18,7 & 15,1 & 28,6 & $-3,6$ & $+13,5$ & $+9,9$ \\
\hline
\end{tabular}

тонн, травяного - 20414 тонн, сена - 584 тонны, соломы - 2841,8 тонны. Большое значение для реализации высокого генетического потенциала продуктивности имеет организация полноценного кормления коров, в соответствии с физиологическими потребностями. С этой целью кормление коров планирует и контролирует специалист из Нидерландов, постоянно проживающий в хозяйстве. Система кормления скота максимально приближена к таковой на их родине.
В 2018 году ООО «Красный маяк» получило статус племзавода по голштинской породе, оставаясь одновременно племрепродуктором по ярославской породе. Здесь используют канадских быков с геномной оценкой, тестируют на хромосомные аномалии производителей, ставят быков племпредприятия ОАО «Ярославское» по племенной работе на оценку по качеству потомства для присвоения племенных категорий, что входит в функции племзавода. Планируют закуп-

Таблица 4 - Рост и развитие молодняка, племпродажа, оценка быков

\begin{tabular}{|c|c|c|c|c|c|c|}
\hline \multirow{2}{*}{ Показатель } & \multicolumn{3}{|c|}{ Год } & \multirow{2}{*}{$\begin{array}{c}2015 \text { г. } \\
\text { к } 2011 \text { г., \% } \\
\end{array}$} & \multirow{2}{*}{$\begin{array}{c}2018 \text { г. } \\
\text { к } 2015 \text { г., \% }\end{array}$} & \multirow{2}{*}{$\begin{array}{c}2018 \text { г. } \\
\text { к } 2011 \text { г., \% }\end{array}$} \\
\hline & 2011 & 2015 & 2018 & & & \\
\hline $\begin{array}{l}\text { Средняя живая масса } \\
\text { в } 10 \text { месяцев, кг }\end{array}$ & 274 & 298 & 310 & 108,8 & 104,0 & 113,1 \\
\hline $\begin{array}{l}\text { Средняя живая масса } \\
\text { в } 12 \text { месяцев, кг }\end{array}$ & 308 & 355 & 365 & 115,2 & 102,8 & 118,5 \\
\hline $\begin{array}{l}\text { Средняя живая масса } \\
\text { в } 18 \text { месяцев, кг }\end{array}$ & 374 & 451 & 456 & 120,6 & 101,1 & 121,9 \\
\hline $\begin{array}{l}\text { Средняя живая масса при } \\
\text { первом осеменении, кг }\end{array}$ & 380 & 420 & 410 & 110,5 & 97,6 & 107,9 \\
\hline $\begin{array}{l}\text { Средний возраст } 1 \text { отёла, } \\
\text { дней }\end{array}$ & 828 & 753 & 716 & 90,9 & 95,1 & 86,5 \\
\hline $\begin{array}{l}\text { Продано племмолодняка, } \\
\text { гол. }\end{array}$ & 10 & 39 & 77 & в 3,9 раза & 197,4 & в 7,7 раза \\
\hline $\begin{array}{l}\text { Находятся быков на оценке, } \\
\text { гол. }\end{array}$ & 2 & 10 & 8 & в 5,0 раза & 80,0 & в 4,0 раза \\
\hline
\end{tabular}


Таблица 5 - Воспроизводство стада

\begin{tabular}{|c|c|c|c|c|c|c|}
\hline \multirow{2}{*}{ Показатель } & \multicolumn{3}{|c|}{ Год } & \multirow{2}{*}{$\begin{array}{c}2015 \text { г. } \\
\text { к } 2011 \text { г., \% }\end{array}$} & \multirow{2}{*}{$\begin{array}{c}2018 \text { г. } \\
\text { к } 2015 \text { г., \% }\end{array}$} & \multirow{2}{*}{$\begin{array}{c}2018 \text { г. } \\
\text { к } 2011 \text { г., \% }\end{array}$} \\
\hline & 2011 & 2015 & 2018 & & & \\
\hline Искусственно осеменено, гол. & 584 & 559 & 2100 & 95,7 & в 3,8 раза & в 3,6 раза \\
\hline Выход телят на 100 коров, гол. & 75,0 & 83,0 & 83,0 & 110,7 & 100,0 & 110,7 \\
\hline Осеменено улучшателями, гол. & 554 & 421 & 1563 & 76,0 & в 3,7 раза & в 2,8 раза \\
\hline Осеменено улучшателями, \% & 94,9 & 76,0 & 74,4 & -18,9 п.п. & -1,6 п.п. & -20,5 п.п. \\
\hline Средний сервис-период, дней & 151 & 123 & 124 & 81,5 & 100,8 & 82,1 \\
\hline
\end{tabular}

ку еще 400 нетелей импортного скота голштинской породы. От лучших коров получают годовые удои свыше 15 тыс. кг молока с высоким содержанием жира и белка. Рекордистки голштинской породы: по 1-й лактации - 15696 кг молока - 4,49\% жира - 3,45\% белка, скорость молокоотдачи 2,733,0 кг/мин.; по 2-й лактации - 15637 кг молока 4,53\% жира - 3,21\% белка, скорость молокоотда- чи 2,21 кг/мин. Из рекордисток ярославской породы: по 1-й лактации - 13023 кг молока - 3,9\% жира - 3,20\% белка; по 2-й лактации - 12481 кг молока - 4,05\% жира - 3,25\% белка.

Планируется создание быкопроизводящей группы коров голштинской породы для получения и постановки в сеть искусственного осеменения высокоценных племенных бычков собст-

Таблица 6 - Экономические показатели по молочному скотоводству в динамике за период 2011-2018 гг.

\begin{tabular}{|l|c|c|c|}
\hline \multirow{2}{*}{ Показатель } & \multicolumn{2}{c|}{ Год } & \multirow{2}{*}{2018 г. к 2011 г., \% } \\
\cline { 2 - 3 } & 2011 & 2018 & \multirow{2}{*}{ в 6,5 раза } \\
\hline Валовый надой молока, ц & 36583 & 236048 & 54,3 п.п. \\
\hline Прибыль от молока к общей выручке по животноводству, \% & 44,3 & 97,7 & 6,66 п.п. \\
\hline Рентабельность производства молока, \% & 20,0 & 26,66 & в 6,5 раза \\
\hline Производство молока в сутки, т & 10,0 & 64,6 & 78,2 \\
\hline Затраты кормов на 1 кг молока, к.ед. & 1,1 & 0,86 & 129,5 \\
\hline Себестоимость 1 ц молока, руб. & 1760 & 2280 & 121,3 \\
\hline Цена реализации 1 ц молока, руб. & 2390 & 2900 & \multicolumn{2}{|c|}{} \\
\hline
\end{tabular}

венной репродукции. В ООО «Красный маяк» уже стали заниматься трансплантацией эмбрионов от высокопродуктивных коров, с привлечением специалистов из Канады. Приживаемость эмбрионов составила 70\%, что является очень высоким показателем. Один бык-трансплантант поставлен в сеть искусственного осеменения, племпредприятию ОАО «Ярославское» по племенной работе, от него накапливают банк спермы. Перспективная цель - иметь своих производителей, более адаптированных к местным условиям, чем импортный скот.

Таким образом, благодаря совместному целенаправленному воздействию генетических и паратипических факторов, созданию оптимальных условий производственного использования животных, организации научно обоснованной системы разведения (что особенно важно для адаптации импортного скота, его сохранности, реализации высокого генетического потенциала молочной продуктивности коров), стадо ООО «Красный маяк» за несколько лет вышло по показателям на мировой уровень. Этот положительный опыт повышения эффективности производственного использования импортного скота целесообразно использовать и в других хозяйствах в целях интенсификации молочного скотоводства и повышения рентабельности отрасли [6].

\section{Выводы}

1. В результате интенсификации молочного скотоводства в хозяйстве ООО «Красный Маяк» производственные показатели значительно повысились, в том числе валовый надой увеличился 
в 6,5 раза, а прибыль от молока составляет большую часть общей выручки.

2. Улучшилось воспроизводство стада, выход телят увеличился до 83\%, повысилась скороспелость ремонтных тёлок - возраст 1-го осеменения уменьшился на 112 дней, при укрупнении живой массы на 5-7\%.

3. Возросла племенная ценность животных стада, что является предпосылкой для дальней- шего роста продуктивных качеств животных и повышения экономической эффективности производства молока в хозяйстве.

Предложение производству - добиваться снижения заболеваемости коров стада по причине маститов и травм, повышать продуктивное долголетие животных, продолжительность хозяйственного использования, особенно ценных племенных коров.

\section{תumepamypa}

1. Доктрина продовольственной безопасности РФ [Текст]: программа. - М., 2010.

2. Тамарова, Р.В. Создание нового типа ярославского скота Михайловского типа методом воспроизводительного скрещивания с использованием генофонда голштинской породы [Текст]: монография / Р.В. Тамарова. - Ярославль: Изд-во ФГОУ ВПО «Ярославская ГСХА», 2002. - 114 с.

3. Тамарова, Р.В. Адаптация коров голштинской породы канадской селекции в условиях молочного комплекса с привязным содержанием животных [Текст] / Р.В. Тамарова // Вестник АПК Верхневолжья. 2016. - № 3 (35). - C. 41-43.

4. Костомахин, Н.М. Голштинская порода крупного рогатого скота [Текст] / Н.М. Костомахин // Главный зоотехник. - 2008. - № 7. - С. 13-14.

5. Ярославский агровестник [Электронный ресурс]. - Режим доступа: http://yariks.info/category/ yaragrovest/.

6. Латышева, О.В. Продуктивные и воспроизводительные качества коров голштинской породы в зависимости от линейной принадлежности [Текст] / О.В. Латышева, В.Ф. Позднякова // Зоотехния. - 2015. № 8. - C. 15-16.

\section{References}

1. Doktrina prodovol'stvennoj bezopasnosti RF [Tekst]: programma. - M., 2010.

2. Tamarova, R.V. Sozdanie novogo tipa jaroslavskogo skota Mihajlovskogo tipa metodom vosproizvoditel'nogo skreshhivanija s ispol'zovaniem genofonda golshtinskoj porody [Tekst]: monografija / R.V. Tamarova. - Jaroslavl': Izd-vo FGOU VPO «Jaroslavskaja GSHA», 2002. - 114 s.

3. Tamarova, R.V. Adaptacija korov golshtinskoj porody kanadskoj selekcii v uslovijah molochnogo kompleksa s privjaznym soderzhaniem zhivotnyh [Tekst] / R.V. Tamarova // Vestnik APK Verhnevolzh'ja. - 2016. № 3 (35). - S. 41-43.

4. Kostomakhin, N.M. Golshtinskaja poroda krupnogo rogatogo skota [Tekst] / N.M. Kostomakhin // Glavnyj zootehnik. - 2008. - № 7. - S. 13-14.

5. Jaroslavskij agrovestnik [Jelektronnyj resurs]. - Rezhim dostupa: http://yariks.info/category/yaragrovest/.

6. Latysheva, O.V. Produktivnye i vosproizvoditel'nye kachestva korov golshtinskoj porody v zavisimosti ot linejnoj prinadlezhnosti [Tekst] / O.V. Latysheva, V.F. Pozdnyakova // Zootehnija. - 2015. - № 8. - S. 15-16. 